\title{
Új molekuláris klasszifikációs rendszerek diffúz nagy B-sejtes limfómában
}

\author{
Kiss Laura ${ }^{1,2}$, Bátai Bence ${ }^{1,2}$, Bödör Csaba ${ }^{1,2}$, Nagy Ákos ${ }^{1,2, @ ~}$ \\ ${ }^{1}$ HCEMM-SE Molekuláris Onkohematológia Kutatócsoport, Budapest \\ ${ }^{2}$ I. Sz. Patológiai és Kísérleti Rákkutató Intézet, Semmelweis Egyetem, Budapest
}

\begin{abstract}
A diffúz nagy B-sejtes limfóma (DLBCL) a leggyakoribb non-Hodgkin-limfóma (NHL), az összes NHL-es eset mintegy 40\%-a tartozik ide. A betegek kétharmada az első vonalbeli kemoimmunterápia hatására meggyógyul, azonban harmaduknál rendkívül agresszív DLBCL alakul ki. A rendelkezésre álló új terápiás lehetőségek ellenére a kemoimmunterápiára rosszul reagáló csoportban a terápiás siker egyelőre várat magára, aminek hátterében a betegség rendkívüli heterogenitása és ebből következően a klinikai vizsgálatokba történő nem megfelelő betegszelekció állhat. A jelenleg alkalmazott DLBCL besorolás a génexpresszió alapján meghatározott sejteredetnek megfelelően három csoportot különít el: a csíracentrum-eredetű (GCB), az aktivált B-sejt-eredetű (ABC) és a nem klasszifikálható DLBCL-es eseteket. Bár a GCB csoportba tartozó eseteknek jellemzően kedvezőbb a kórlefolyása, mint az ABC csoportba tartozóké, az egyes csoportokon belül továbbra is rendkívül sokszínű a várható kórlefolyás. A molekuláris diagnosztikai módszerek utóbbi évtizedekben látott fejlődésének köszönhetően olyan molekuláris eltérésekre derült fény, melyek egy új klasszifikációs rendszer alapköveiként szolgálhatnak. Az új, molekuláris genetikai klasszifikáción alapuló modellek célja olyan prognosztikus és prediktív biomarkerek azonosítása, amelyek elősegíthetik a betegek személyre szabott rizikóstratifikációját, valamint potenciális terápiás célpontként szolgálhatnak. Jelen összefoglaló közleményünkben a DLBCL-lel kapcsolatos legfrissebb molekuláris genetikai eredményeket tekintjük át.
\end{abstract}

Kulcsszavak: diffúz nagy B-sejtes limfóma, mutációs profil, génexpressziós profil, prognózisbecslés

\section{New molecular classification systems in diffuse large B-cell lymphoma}

Diffuse large B-cell lymphoma is considered to be the most common non-Hodgkin lymphoma, representing $40 \%$ of all cases. While almost two third of DLBCL patients can be cured using first line chemoimmunotherapy, the remaining patients develop refractory or relapsed disease with poor outcomes. Despite the wide range of therapeutic options, the success rate in patients poorly responding to chemoimmunotherapy has not met the expectations, potentially resulting from the molecular heterogeneity of the disease. The DLBCL classification used in current diagnostic routine distinguishes three groups based on cell of origin: germinal center B-cell-like, activated B-cell-like and unclassified cases. Even though the GCB subgroup generally has a favorable outcome, compared to the ABC group, there is still a remarkable heterogeneity in each group regarding individual prognosis. Owing to the advances of molecular diagnostic methods, the recently described molecular alterations may serve as cornerstones of a new classification system. Current research focuses on incorporating alterations harboring prognostic or predictive significance into molecular genetic classification systems moving one step closer to paradigm shift in lymphoma management: integrating personalized precision medicine into clinical practice. Hereby, we review the most recent genetic studies, and we provide an overview and comparison of the novel molecular-based DLBCL classification systems published in the past few years.

Keywords: diffuse large B-cell lymphoma, mutation profile, gene expression profile, prognosis assessment

(Beérkezett: 2021. május 25.; elfogadva: 2021. június 1.)

@ Levelezési cím: Dr. Nagy Ákos, 1085 Budapest, Üllői út 26.; Tel: +36-30-531-0236; E-mail: nagy.akos1@med.semmelweis-univ.hu 


\section{Rövidítések}

ABC-DLBCL - aktivált B-sejt-eredetü DLBCL; BCR - B-sejtreceptor; $\mathrm{COO}$ - sejteredet; DA-EPOCH-R - dose-adjusted etoposide, prednisolone, vincristine, cyclophosphamid, doxorubicin és rituximab kombinációja; DEL - double-expressor limfóma; DHITsig - double hit signature; DHL - double-hit limfóma; DLBCL - diffúz nagy B-sejtes limfóma; DLBCL NOS - tovább nem osztályozható DLBCL; FFPE - formalinfixált paraffinba ágyazott szövetminta; FL - follikuláris limfóma; GCB-DLBCL - csíracentrum-eredetű DLBCL; G-CHOP - obinutuzumab, cyclophosphamid, doxorubicin, vincristine és prednison kombinációja; IPI - nemzetközi prognosztikus index; MHG-DLBCL - molecular high grade DLBCL; NCI Amerikai Nemzeti Rákkutató Intézet; NEC - not elsewhere classified; NHL - non-Hodgkin-limfóma; OS - várható túlélés; PFS - progressziómentes túlélés; r/rDLBCL - relabáló-refrakter DLBCL; R-CHOP - rituximab, cyclophosphamid, doxorubicin, vincristine és prednison kombinációja; $\mathrm{tFL}$ - transzformált follikuláris limfóma; THL - triple-hit limfóma; WES - teljes exomszekvenálás; WHO - Egészségügyi Világszervezet

\section{Bevezetés}

A diffúz nagy B-sejtes limfómák (DLBCL) a leggyakoribb non-Hodgkin-limfómák, melyek klinikailag sokszínü csoportot alkotnak [1]. Bár a betegek többsége kemo- immunterápiával (leggyakrabban R-CHOP: rituximab, cyclophosphamid, doxorubicin, vincristine és prednison) meggyógyítható, egyharmaduknál rossz prognózisú, nehezen kezelhető relabáló-refrakter betegség (r/rDLBCL) alakul ki [2]. A modern terápiás eljárások egyre bővülő listája (jelátviteli útvonalgátlók, monoklonális antitestek, immunellenőrzőpont-gátlók, kiméra antigén receptor T-sejt-terápiák) ellenére ezen esetek sikeres kezelése egyelőre várat magára. A jelenség hátterében a betegség rendkívüli molekuláris heterogenitása állhat. Az Egészségügyi Világszervezet (WHO) által kiadott legfrissebb, a napi klinikai gyakorlatban is alkalmazott klasszifikáció is számos entitást különít el, bár a szervspecifikus altípusok mellett vírusfertőzéssel, krónikus gyulladással és jellegzetes visszatérő genetikai eltérésekkel asszociált formák mellett a legtöbb eset a tovább nem osztályozható csoportba (DLBCL NOS - not otherwise specified) tartozik (1. táblázat) [3].

A 2016-os WHO-osztályozásban már molekuláris eltéréseket figyelembe vevő, jellemzően kedvezőtlen kórlefolyású entitások is megjelentek, melyeket összefoglalóan high grade B-sejtes limfómáknak (MYC, BCL2 és/ vagy BCL6 transzlokációkkal rendelkező double-hit vagy triple-hit limfómák [DHL, THL]) nevezünk (1. táblázat).

1. táblázat. Az Egészségügyi Világszervezet (WHO) jelenlegi gyakorlatban alkalmazott klasszifikációs rendszere (2016)

Érett B-sejtes limfoid neoplazmák WHO-klasszifikációja (2016)

Diffúz nagy B-sejtes limfóma (DLBCL), NOS

Centrum germinatívum B-sejt-eredetű (GCB)

Aktivált B-sejt eredetű (ABC)

T-sejt-, hisztiocitagazdag DLBCL

Központi idegrendszeri primer DLBCL

$\mathrm{EBV}+\mathrm{DLBCL}, \mathrm{NOS}$

$\mathrm{EBV}+$ mucocutan fekély

Krónikus gyulladásasszociált DLBCL

Limfomatoid granulomatosis

Primer mediasztinális DLBCL

Intravaszkuláris DLBCL

ALK + DLBCL

Plazmoblasztos limfóma

Primer effúziós limfóma

HHV8 + DLBCL, NOS

Burkitt-limfóma

Burkitt-szerű limfóma 11q-aberrációval

High-grade B-sejtes limfóma MYC-, BCL2- és/vagy BCL6-átrendeződéssel

High-grade B-sejtes limfóma, NOS

B-sejtes limfóma, nem klasszifikálható, a DLBCL és a klasszikus Hodgkin-limfóma között átmeneti tulajdonságokkal rendelkezik

EBV - Epstein-Barr-vírus; DLBCL NOS - tovább nem osztályozható DLBCL; HHV8 - humán herpeszvírus 8 
További molekuláris eltérésként Alizadeh és mtsai által meghatározott génexpressziós alapú sejteredet-csoportosítás is megjelent DLBCL NOS csoporton belül a WHO legfrissebb klasszifikációs rendszerében [4]: a centrum germinativum-eredetü ( $G C B$, a DLBCL-es esetek 56\%-a), az aktivált B-sejt-eredetű ( $A B C, 32 \%)$ és az előző két csoportba nem sorolható DLBCL (unclassified, 12\%). Bár a sejteredet $(\mathrm{COO})$ szerinti beosztás képes elkülöníteni a kedvezőtlen lefolyású ABC-DLBCL csoportot (5 éves várható túlélés, OS: $56 \%$ ) a kedvező prognózisú GCBDLBCL csoporttól (5 éves OS: 78\%), az egyes altípusokon belül előforduló eltérő prognózissal rendelkező eseteket szelektíven nem lehet a módszerrel azonosítani, ezért klinikai szempontból továbbra is elengedhetetlen lenne egy új, pontosabb klasszifikációs rendszer kidolgozása.

\section{Terápiás próbálkozások az egyes DLBCL alcsoportokban}

A kedvezőbb prognózisú GCB-DLBCL betegcsoporton belül sem az összes eset reagál jól R-CHOP-kezelésre (mely esetek jelentős hányada a DHL/THL csoportba tartozik), kézenfekvőnek tünik tehát, hogy ezen betegcsoport erősebb kemoimmunterápiás kombinációkkal hatékonyabban kezelhető. Bár több tanulmány is a DAEPOCH-R (dose-adjusted etoposide, prednisolone, vincristine, cyclophosphamid, doxorubicin és rituximab) kombináció jótékony hatását mutatta ki [5-7], a fázis III
ALLIANCE-vizsgálatban nem volt egyértelmü kimutatható előny a kombináció alkalmazásával R-CHOP-hoz képest [8]. A standard terápiákra jellemzően rosszul reagáló aktivált B-sejt-eredetű DLBCL-es eseteknél is fokozott igény mutatkozik új terápiákra. Több sikeres fázis Ia/b és fázis II klinikai tanulmányban teszteltek célzott terápiákat ebben a betegcsoportban, azonban eddig egyetlen fázis III tanulmányban sem sikerült kimutatni ezen terápiák fokozott hatékonyságát a standard kezeléshez képest. Ilyen potenciális terápiás ágensre irányuló tanulmány volt a REMoDL-B- (bortezomib - proteaszómagátló) [9], a PHOENIX- (ibrutinib - bruton tirozin kinázgátló) [10] és a ROBUST- (lenalidomid - immunmoduláns szer) [11] vizsgálat. A CAVALLI-tanulmányban a double-expressor limfómák (DEL) esetén (BCL2- és $c$-MYC-overexpresszió) a venetoclax kemoimmunterápiához (R-CHOP vagy G-CHOP [G: obinutuzumab]) való kombinációja ígéretesnek bizonyult [12], azonban ebben a vizsgálatban sem tudtak szignifikáns túlélésbeli előnyt igazolni a COO alapján klasszifikált csoportoknál (2. táblázat) [13]. A klinikai tanulmányok sikertelenségének hátterében a DLBCL korábban már említett $\mathrm{ABC} /$ GCB-DLBCL klasszifikációján túlmutató heterogenitása mellett az állhat, hogy a klinikai tanulmányokba jellemzően alacsonyabb stádiumú, jobb állapotú (fit) betegeket vontak be, mely betegcsoportnál nehezebben igazolható az új szerek standard kemoimmunterápiákhoz adott értéke. A pontosabb klasszifikáció mellett tehát fontos lesz a rossz állapotú betegek bevonása az új, prospektív tanul-

2. táblázat. Az aktivált B-sejt-eredetű DLBCL esetek új célzott terápiás kezelési algoritmusára irányuló klinikai vizsgálatok részletezése

\begin{tabular}{|c|c|c|c|c|c|}
\hline $\begin{array}{l}\text { Klinikai } \\
\text { vizsgálat }\end{array}$ & Fázis & $\begin{array}{l}\text { Terápiás } \\
\text { protokoll }\end{array}$ & Diagnózis & Eredmény & Megjegyzések \\
\hline REMoDL-B & Fázis III & $\begin{array}{l}\text { „R-CHOP vs. } \\
\text { R-CHOP + } \\
\text { bortezomib” }\end{array}$ & DLBCL & $\begin{array}{l}\text { „30 hónapos PFS: } 70,1 \% \text { vs. } 74,3 \% \\
\text { Nincs különbség a PFS és OS } \\
\text { szempontjából GCB és ABC } \\
\text { DLBCL között.” }\end{array}$ & $\begin{array}{l}\text { COO klasszifikációt génexpresz- } \\
\text { sziós profilozással határozták meg. } \\
\text { Bortezomibbal a második ciklustól } \\
\text { egészítették ki a terápiát }\end{array}$ \\
\hline PHOENIX & Fázis III & $\begin{array}{l}\text { R-CHOP vs. } \\
\text { R-CHOP + } \\
\text { ibrutinib }\end{array}$ & $\begin{array}{l}\text { non-GCB- } \\
\text { DLBCL }\end{array}$ & Nem volt különbség a EFS-ben & $\begin{array}{l}\text { COO-klasszifikációt immunhisz- } \\
\text { tokémiával (Hans-algoritmussal) } \\
\text { határozták meg, melyet az első } \\
\text { ciklust követően génexpressziós } \\
\text { profilozással egészítettek ki. Ibru- } \\
\text { tinib + R-CHOP esetén kedvezőbb } \\
\text { EFS, PFS és OS igazolódott } 60 \text { évnél } \\
\text { fiatalabb betegek esetén }\end{array}$ \\
\hline ROBUST & Fázis III & $\begin{array}{l}\text { „R-CHOP vs. } \\
\text { R-CHOP + } \\
\text { lenalidomid” }\end{array}$ & $\begin{array}{l}\text { ABC- } \\
\text { DLBCL }\end{array}$ & Nem volt különbség a PFS-ben & $\begin{array}{l}\text { COO-klasszifikációt NanoStringgel } \\
(\text { Lymph2Cx) határozták meg }\end{array}$ \\
\hline CAVALLI & Fázis Ib/II & $\begin{array}{l}\text { "R-CHOP + } \\
\text { venetoclax vs. } \\
\text { G-CHOP + } \\
\text { venetoclax” }\end{array}$ & $\begin{array}{l}\text { "high risk" } \\
\text { DLBCL }\end{array}$ & $\begin{array}{l}\text { CR: } 69,2 \% \text { (hasonló a GOYA- } \\
\text { tanulmány CR-értékéhez) }\end{array}$ & $\begin{array}{l}\text { PFS magasabb a vártnál (GOYA-vizs- } \\
\text { gálattal összehasonlítva) DEL-ben } \\
\text { szenvedő betegek esetén }\end{array}$ \\
\hline
\end{tabular}

R-CHOP - rituximab, cyclophosphamid, doxorubicin, vincristine és prednison kombinációja; G-CHOP - obinutuzumab, cyclophosphamid, doxorubicin, vincristine és prednison kombinációja; DLBCL - diffúz nagy B-sejtes limfóma; ABC-DLBCL aktivált B-sejt-eredetű DLBCL; GCB-DLBCL - csíracentrum-eredetű DLBCL; CR - teljes remisszió; OS - várható túlélés; PFS progressziómentes túlélés; EFS - eseménymentes túlélés; COO - sejteredet-alapú klasszifikáció; DEL - double expressor limfóma 
mányokba, mely betegek esetén a kezelés megkezdésének sürgőssége miatt egy olyan új klasszifikációs rendszer kialakítására lesz szükség, melynek a rövid „átfutási ideje” lehetővé teszi a kezelésre szoruló esetek gyors klasszifikációját $[14,15]$.

\section{Új molekuláris klasszifikáció DLBCL-ben: génexpresszió-alapú vizsgálatok}

A génexpresszió-alapú vizsgálatok elsősorban a GCBDLBCL altípuson belüli kedvezőtlen prognózisú limfómák elkülönítését tűzték ki célul. Ennishi és mtsai 157 de novo DLBCL eset génexpressziós és mutációs profilját vizsgálták NanoString technológia alkalmazásával, teljes exomszekvenálással (WES) és célzott RNS-szekvenálással [16]. Bár FISH-sel csak a betegek 13\%-a tartozott a DHL csoportba, az esetek további $14 \%$-ánál a DHL csoportra jellemző génexpressziós profilt tudtak kimutatni, mely mintázatot DHITsig-nek (double hit signature) nevezték el. A DHITsig+, de nem klasszikus DHL-es betegek kórlefolyása hasonló volt, mint a FISH-sel kimutatott
DHL-lel rendelkezőké. Ezen esetek (DHITsig+, DHL-) teljes genomszekvenálása során kriptogén, atipikus törésponttal jellemzett $M Y C$-transzlokációk mellett a $M Y C$ és a $M I R 17 H G$-gének amplifikációit, illetve a PVT1 long non-coding RNS-gén promóterének delécióját mutatták ki, melyek szerepet játszhatnak a $M Y C$-diszreguláció folyamatában [17].

Egy másik, hasonló tanulmányban Sha és mtsai a REMoDL-B klinikai vizsgálat 928 DLBCL-es betegét vizsgálták teljes transzkriptomszekvenálással [18]. A kutatás eredményeként az esetek 9\%-ában azonosítottak egy kedvezőtlen kórlefolyást (3 éves progressziómentes túlélés, PFS: 37\%) előre jelző génexpressziós mintázatot (90\%-ban GCB eredettel társulva), melyet magas molekuláris grádusú (molecular high grade, MHG) DLBCL-nek neveztek el. Az MHG-DLBCL-es esetek mutációs spektrumának vizsgálata során follikuláris limfóma/transzformált follikuláris limfóma- (FL/tFL-) asszociált mutációkat és olyan $M Y C$-gén eltéréseket (fúzió, visszatérő mutációk az 56-60. kodonokban) azonosítottak, melyek szerepet játszanak a $M Y C$ intracelluláris lebontásának gát-

3. táblázat. 2018-2020 között kidolgozott DLBCL-klasszifikációs rendszerek összefoglalása. Az egyes vizsgálatok által felállított csoportok párhuzamba állítása mellett jelöltük azokat a géneket, melyek molekuláris eltérései a klasszifikációs rendszerek kialakításának alapját képezték. Az új csoportok esetében feltüntettük a jelenleg alkalmazott, sejteredet-alapú beosztásban elfoglalt helyüket is. Emellett kiegészítettük a klasszifikációs adatokat az adott csoport klinikai jelentőségével: az egyes csoportok várható prognózisával, az adott klaszterben potenciális terápiás célpontként szolgáló génekkel és a hasonló genetikai hátterü limfómák megnevezésével is

\begin{tabular}{|c|c|c|c|c|c|c|c|}
\hline $\begin{array}{l}\text { Chapuy } \\
\text { et al. }\end{array}$ & $\begin{array}{l}\text { Lacy } \\
\text { et al. }\end{array}$ & $\begin{array}{l}\text { Wright } \\
\text { et al. }\end{array}$ & $\begin{array}{l}\text { Mutációs } \\
\text { profil }\end{array}$ & $\begin{array}{l}\text { Génexpressziós } \\
\text { profil }\end{array}$ & Prognózis & $\begin{array}{l}\text { Potenciális } \\
\text { célpont }\end{array}$ & $\begin{array}{l}\text { Hasonló genetikai } \\
\text { hátterű lymphomák }\end{array}$ \\
\hline $\mathrm{C} 1$ & NOTCH2 & $\mathrm{BN} 2$ & $\begin{array}{l}\text { BCL6, NOTCH2, } \\
\text { CD70, BCL10, } \\
\text { SPEN }\end{array}$ & $\mathrm{ABC} / \mathrm{GCB}$ & jó/rossz & $\begin{array}{l}\text { BTK, PI3K, } \\
\text { BCL2, PD-L1, } \\
\text { PD-L2 }\end{array}$ & MZL \\
\hline $\mathrm{C} 2$ & - & A53 & TP53, CNA-k & $\mathrm{ABC} / \mathrm{GCB}$ & $\begin{array}{l}\text { közepes } \\
\text { (kontextus- } \\
\text { függó) }\end{array}$ & BTK & \\
\hline \multirow[t]{2}{*}{$\mathrm{C} 3$} & \multirow[t]{2}{*}{ BCL2 } & EZB MYC+ & \multirow{2}{*}{$\begin{array}{l}\text { BCL2, EZH2, } \\
\text { TNFRSF14, } \\
\text { CREBBP, EP300, } \\
\text { KMT2D, STAT6, } \\
\text { MTOR, GNA13 }\end{array}$} & $\begin{array}{l}\text { GCB, MYC+, } \\
\text { MHG, DHTsig } \\
\text { gyakoribb }\end{array}$ & rossz & $\begin{array}{l}\mathrm{EZH} 2, \mathrm{BCL} 2, \\
\mathrm{PI} 3 \mathrm{~K}\end{array}$ & \multirow[t]{2}{*}{ FL } \\
\hline & & EZB MYC- & & GCB & jó & $\begin{array}{l}\text { EZH2, BCL2, } \\
\text { PI3K }\end{array}$ & \\
\hline \multirow[t]{2}{*}{$\mathrm{C} 4$} & $\begin{array}{l}\text { TET2/ } \\
\text { SGK1 }\end{array}$ & \multirow[t]{2}{*}{ ST2 } & $\begin{array}{l}\text { SGK1, TET2, } \\
\text { P2RY8, hiszton } \\
\text { gének }\end{array}$ & \multirow[t]{2}{*}{ GCB } & \multirow[t]{2}{*}{ nagyon jó } & \multirow[t]{2}{*}{ PI3K, JAK } & \multirow{2}{*}{$\begin{array}{l}\text { NLPHL, THRBCL, } \\
\text { PMBCL }\end{array}$} \\
\hline & $\begin{array}{l}\text { SOCS1/ } \\
\text { SGK1 }\end{array}$ & & $\begin{array}{l}\text { SGK1, SOCS1, } \\
\text { hiszton gének }\end{array}$ & & & & \\
\hline $\mathrm{C} 5$ & MYD88 & MCD & $\begin{array}{l}\text { MYD88, CD79B, } \\
\text { PIM1, SPIB, } \\
\text { CDKN2A }\end{array}$ & $\mathrm{ABC}$ & nagyon rossz & $\begin{array}{l}\text { BTK, PI3K, } \\
\text { BCL2, JAK, } \\
\text { IRF4 }\end{array}$ & $\begin{array}{l}\text { extranodalis lym- } \\
\text { phomák, PCNSL }\end{array}$ \\
\hline- & NOTCH2? & N1 & $\begin{array}{l}\text { NOTCH1, } \\
\text { IRF2BP2, } \\
\text { BCOR, IKBKB }\end{array}$ & $\mathrm{ABC}$ & nagyon rossz & PD-1, PD-L1 & \\
\hline
\end{tabular}

ABC-DLBCL - aktivált B-sejt-eredetű DLBCL; GCB-DLBCL - csíracentrum-eredetű DLBCL; MHG-DLBCL - molecular high grade DLBCL; DHITsig - double hit signature; MZL - marginális zónalimfóma; FL - follikuláris limfóma; NLPHL - noduláris limfocita predomináns Hodgkin-limfóma; THRBCL - szöveti hisztiocitagazdag B-sejtes limfóma; PMBCL - primer mediasztinális B-sejtes limfóma; PCNSL - primer központi idegrendszeri limfóma 
lásában, ezzel a Myc fehérje akkumulációjában, mely magyarázza ezen limfómák agresszív klinikai viselkedését [19].

A DLBCL-es sejtek mikrokörnyezetének vizsgálata további hasznos információkkal szolgálhat egy új klasszifikációs rendszer megalkotásakor. Az egyik első, a tumor mikrokörnyezet sejtjeinek génexpressziós vizsgálatát részletező tanulmány kedvező (aktív immunválaszt jelző Stromal-1 profil) és kedvezőtlen (fokozott érújdonképződést jelző Stromal-2 profil) kórlefolyást jelző mintázatokat tudott elkülöníteni DLBCL-es betegek mintáinak vizsgálatával [20], míg egy újabb tumor-mikrokörnyezetet vizsgáló tanulmányban rossz prognózisú DLBCL-es betegek esetén tudtak limfómaasszociált makrofág-génexpressziós mintázatot azonosítani [21].

\section{Új molekuláris klasszifikáció DLBCL-ben: gén- és kromoszómaszintü vizsgálatok}

Számos kutatócsoport dolgozik jelenleg is azon, hogy modern molekuláris profilozással (WES, célzott szekvenálás, RNS-szekvenálás) olyan célozható genetikai eltéréseket azonosítson, melyek egy új klasszifikációs rendszer mindennapi betegellátásba való beemelésének első lépéseit szolgálhatják. Ezen tanulmányokban összesen mintegy 2000 de novo DLBCL-es beteg mintáját vizsgálták, melyekben több mint 150 gén patogén mutációit azonosították.

Schmitz és mtsai (Amerikai Nemzeti Rákkutató Intézet [NCI] munkacsoport) 574 de novo DLBCL-es eset diagnosztikus friss fagyasztott mintáját vizsgálták [22]. A vizsgálat során négy új genetikai szubtípust definiáltak a WES segítségével azonosított visszatérő molekuláris eltérések (mutációk, kópiaszám-változások, transzlokációk) alapján. Az új csoportokat MCD (CD79B, MYD88 molekuláris eltérésekkel jellemezhető csoport), BN2 (NOTCH2, BCL6), N1 (NOTCH1) és EZB (EZH2, BCL2) megjelöléssel illették, melyekbe az összes eset 46,6\%-át sikerült besorolniuk (3. táblázat). A négy csoport szignifikánsan eltérő túlélési mutatókkal rendelkezett R-CHOP kombinációval végzett kezelést követően: a legrosszabb túlélési mutatókkal az $M C D$ alcsoport bírt, ezen esetek sejteredet szerint jellemzően az ABC-DLBCL csoportba tartoztak, továbbá a már említett $C D 79 B$ - és $M Y D 88$-mutációk mellett az NF- $\kappa \mathrm{B} / \mathrm{B}$-sejt receptor- (BCR-) jelátviteli út kóros aktivitása volt rájuk jellemző. A $B N 2$ alcsoport fényt deríthet a génexpresszió alapján eddig nem besorolható DLCBL-ek közé sorolt esetek egy részének molekuláris hátterére. A csoportot a NOTCH2-mutáció és BCL6-fúzió, illetve az MCD-hez hasonlóan az NF- $\mathrm{B}$ / $\mathrm{BCR}$ jelátviteli út kóros aktivitása jellemzi. Az ABCDLBCL eredetü N1 csoportban a NOTCH1-mutáció mellett a kifejezett T-sejtes infiltráció gyakori. A döntően GCB-DLBCL sejteredetü $E Z B$ csoportot az EZH2-mutációk és BCL2-transzlokációk jellemezték, mely csoport rendelkezett a legjobb túlélési mutatókkal R-CHOPkezelést követően a BN2 csoport mellett (3. táblázat).

Chapuy és mtsai (Harvard munkacsoport) szintén 2018-ban közölték eredményeiket, azonban a kutatásuk során több ponton is eltérő módszereket alkalmaztak [23]. A különbségek közül kiemelendő, hogy az általuk vizsgált 304 R-CHOP-kezelt DLBCL-es beteg diagnosztikus friss fagyasztott mintái mellett formalinfixált paraffinba ágyazott (FFPE) anyagokat is vizsgáltak. WES, célzott szekvenálás és 137 mintán végzett RNS-szekvenálás segítségével öt új molekuláris csoportot különítettek el (C1-C5), melyekbe az esetek 96\%-át tudták besorolni. Ezek mellett egy addicionális csoport (CO) is körvonalazódott, melyben nem találtak detektálható eltéréseket, egyedül csak a gazdag immunsejtes infiltráció volt gyakori. A sejteredet-alapú felosztás átlagos túlélési mutatójához képest, ebben a klasszifikációban a molekuláris háttér alapján elkülönültek az ABC és GCB csoportokon belüli jó és rossz prognózisú alcsoportok. A sejteredet-alapú felosztás szerinti $\mathrm{ABC}$ szubtípussal leginkább a $\mathrm{C} 1$ és a $\mathrm{C} 5$ alcsoport fed át, melyek közül kedvezőbb prognózisú a $C 1$ csoport, melyet BCL6-transzlokációk, NOTCH2- és SPEN-mutációk, illetve az NF- $\mathrm{BB}$ útvonal tagjainak mutációi jellemeznek (3. táblázat). A C5 csoportba tartozó eseteknél kedvezőtlenebb prognózis volt megfigyelhető, mely szubtípusban a BCL2- és $M Y D 88^{L 265 P} / C D 79 B$-variánsok a jellemzőek. A C3 és C4 csoport esetei föként a GCB-DLBCL csoportba tartoznak. A $C 3$ klaszter jellemző genetikai eltérései a $B C L 2-, E Z H 2$-mutációk, PTEN-inaktiváció és a BCR útvonalat érintő eltérések, míg a $C 4$ kategóriában a core és linker (kifejezetten a $\mathrm{H} 1$ ) hisztonokban azonosított anomáliák mellett a BCR, a JAK/STAT és az NF- $\kappa \mathrm{B}$ jelátviteli utak rendellenességei gyakoriak. A két osztály prognózisbeli különbségét tekintve a $\mathrm{C} 4$ esetek rendelkeznek túlnyomórészt kedvezőbb kimenetellel. A $C 2$ alcsoportban a TP53 biallélikus inaktivációját azonosították, emellett sérült a kromoszómák és a sejtciklus stabilitása is. Ebbe a csoportba mind ABC, mind GCB-DLBCLes esetek is besorolhatók (3. táblázat).

Lacy és mtsai (Cambridge-i Egyetem munkacsoportja) 2020-ban megjelent tanulmánya során 928 nem előszelektált DLBCL NOS és egyéb specifikus DLBCL entitásba tartozó eseteket vizsgáltak (real-life cohort) [24]. 579 de novo R-CHOP-kezelt esetben az ötéves túlélési adatokat felhasználva tudtak következtetéseket levonni az egyes csoportok prognosztikus értékéről. Limitációként kiemelendő, hogy a tanulmányban a kópiaszám-változásokat és strukturális variánsokat nem vizsgálták. Kutatásuk eredményeként öt csoportot jelöltek ki: a MYD88, BCL2, SOCS1/SGK1, TET2/SGK1 és a NOTCH2 klasztert (3. táblázat). Az esetek 27\%-át nem tudták besorolni a felállított osztályokba (NEC: not elsewhere classified), mely kategórián belül körvonalazódott egy kisebb NOTCH1-mutációval rendelkező csoport, mely csoportot a rá jellemző különösen rossz prognózis miatt érdemes megemlíteni. Kedvezőtlen prognózisú alcsoport a döntően ABC-DLBCL eseteket magában foglaló MYD88 
klaszter. A jó prognózisú $B C L 2$ csoportba tartozó eseteket a KMT2D-, CREBBP-, EP300-, TNFRSF14-, BCL2- és az EZH2-génmutációk jellemzik. További kedvező kimenetelü eseteket tartalmaztak a $S O C S 1 / S G K 1$ és a TET2/ SGK1 klaszterek (3. táblázat). A NOTCH2 és NEC klaszterek intermedier prognózisúnak bizonyultak a tanulmányban, érdekesség, hogy a NOTCH2 DLBCL magába foglal sejteredet alapján mindhárom csoportba besorolható eseteket is. Nem különítettek el individuális csoportot a TP53-mutációval rendelkező eseteknek, azonban kimutatták, hogy a TP53-mutációk prognosztikus értéke kontextusfüggő: rosszabb prognózist eredményez, ha BCL2 és NEC csoportokban jelenik meg, és kifejezetten negatívan befolyásolja a MYD88 csoportba tartozó esetek kórlefolyását. A NOTCH2 és SOCS1/SGK1 csoportokban a TP53-mutáció prognosztikailag semleges, míg a TET2/ SGK1 szubtípusban szinte alig fordul elő az eltérés. Ehhez hasonlóan, a $M Y C$-gén mutációinak jelenléte a BCL2 csoportban eredményezett kedvezőtlenebb kórlefolyást.

Az NCI munkacsoport 2020-ban közölt tanulmányában hét szubtípusra egészítette ki a korábban definiált négy alcsoportot [25]. A Harvard munkacsoport 304 esetét és egy másik tanulmány 332 fős betegcsoportját [16] alapul véve egy bővített klasszifikációs modellt (LymphGen) hoztak létre, amely bárki számára online elérhető (https://llmpp.nih.gov/lymphgen/index.php). A korábban leírt MCD, BN2, N1 és EZB csoportok mellé az ST2, A53 és a „genetikailag kompozit limfóma” (eltérései alapján egyszerre legalább két csoportba besorolható) altípusokat határozták meg (1. ábra). Az új klasszifikációs modell eredményeként a besorolható esetek százalékos aránya 16,5\%-kal (53,4\%-ról 63,1\%-ra) emelkedett. A korábbi tanulmányukban nem osztályozható csoportba sorolt tumorok jelentős része mutációkat és/vagy deléciókat hordozott a TP53-génben, mely eseteket az új modellben az A53 nevü csoportba sorolták (aneuploidia + TP53-inaktiváció). Az új csoportban 55\%-ban ABC és 40\%-ban GCB-DLBCL esetek szerepelnek, valamint kedvezőtlen kimenetel jellemzi ezeket. Az eredeti tanulmányukban nem osztályozható alcsoportba tartozó minták további három gén ( $S G K 1$, TET2 és a $P 2 R Y 8)$ visszatérő, gyakran egymással párhuzamosan jelen lévő mutációit azonosították, melyeket az új ST2 alcsoportba soroltak, melyre jellemzőek a JAK/STAT szignalizációs út elemeinek mutációi. Az ide sorolt esetek döntő többsége csíracentrum-eredetü GCB-DLBCL. Az EZB csoportban prognosztikai szempontból két eltérő szubtípust különböztettek meg: a jobb túlélési mutatókkal rendelkező $E Z B M Y C$ - és a kedvezőtlen prognózissal jellemezhető $E Z B M Y C+$ eseteket (3. táblázat). Az utóbbi kategóriába tartozó limfómák molekuláris háttér alapján a high-grade B-sejtes limfómának (DHL, THL), illetve a transzformált follikuláris limfómának felelnek meg.

\section{Az új molekuláris DLBCL alcsoportok átfedései}

Az elmúlt két év molekuláris genetikai tanulmányai lényegesen bővítették a DLBCL-lel kapcsolatos ismereteinket, így egy új klasszifikációs rendszernek lehetnek az

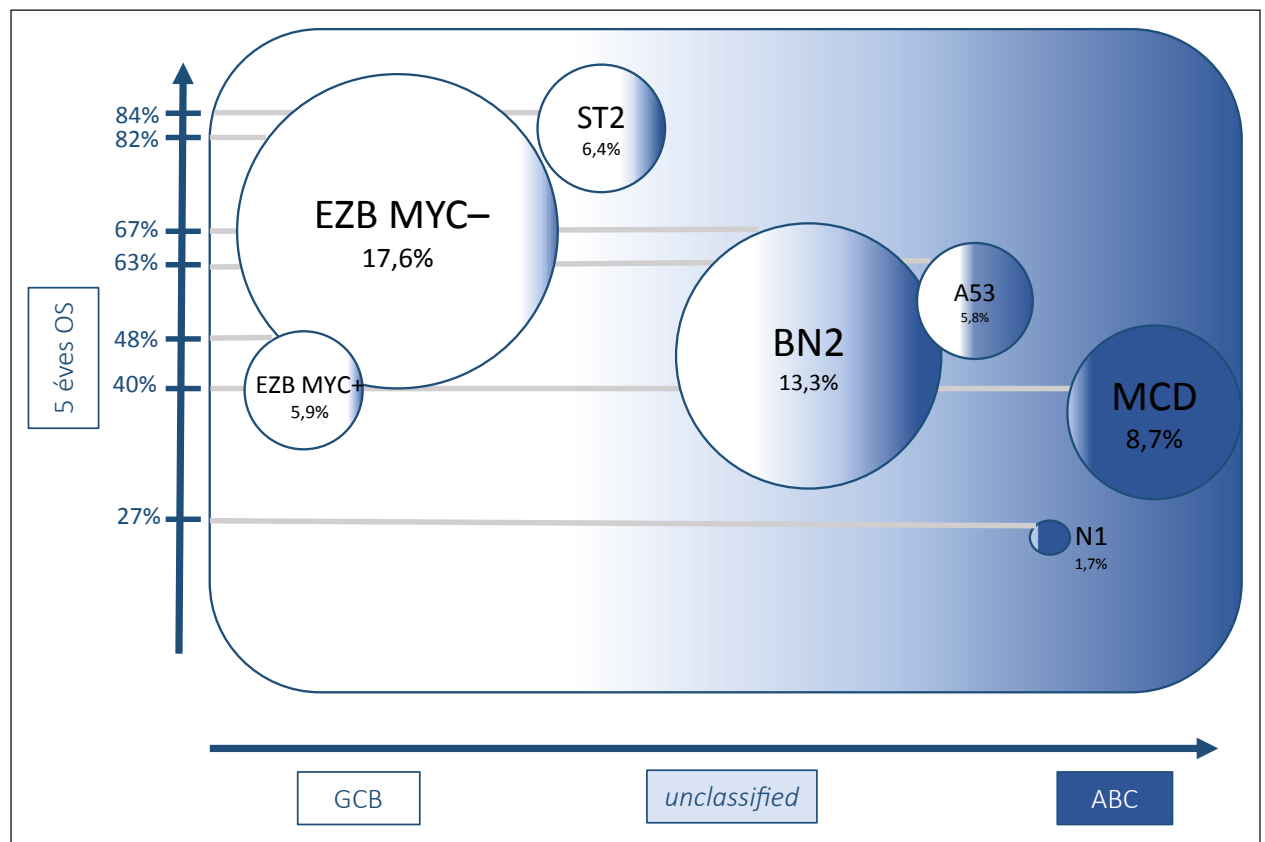

1. ábra. Wright és mtsai által kidolgozott DLBCL-klasszifikációs rendszer szemléltetésére szolgáló diagram. Az egyes körök a DLBCL szubtípusokat jelölik, minden csoport esetén feltüntettük, hogy a klasszifikált esetek (összes vizsgált eset 63,1\%-a) hány százalékát adja az adott DLBCL szubtípus (a kör mérete az alcsoport gyakoriságával arányos). Az $x$ tengely mentén a sejteredet-alapú klasszifikációval feleltettük meg az egyes új klasztereket, míg az y tengely mentén prognosztikus adatként az 5 éves OS (overall survival) százalékos arányát tüntettük fel (ABC-DLBCL - aktivált B-sejt-eredetű DLBCL; GCB-DLBCL - csíracentrum-eredetű DLBCL) 
előfutárai, melynek segítségével a prognózis és az egyes terápiákra adott válasz pontosabban prediktálható [2225]. Az újonnan kialakított csoportok között a $M Y C-\mathrm{EZB}$ DLBCL-es esetek bizonyultak a legbiztatóbb kimenetelünek (5 éves OS: $82 \%$ ), emellett a prevalenciája is ennek a csoportnak a legmagasabb (17,6\%) (1. ábra). $\mathrm{Az}$ $M Y C+$ EZB esetek prognózisa lényegesen kedvezőtlenebb (5 éves OS: 48\%), ebbe a kategóriába tartozik a $M Y C$-transzlokáció pozitív és a DHL/THL esetek nagy része, így az MHG-DLBCL-ek és DHITsig+ DLBCL-ek is (3. táblázat). A két csoport elkülönítése azért is fontos, mert ezzel várhatóan elkülöníthetővé válhatnak a standard terápiára jól és rosszul reagáló GCB-DLBCL-es esetek. Az EZB csoportba tartozó esetekkel fed át a Harvard munkacsoport C3, illetve Lacy és mtsai BCL2 klasztere (3. táblázat). A molekuláris profil jellemző eltérései az EP300-, KMT2D-, STAT6-, mTOR-, GNA13-, BCL2-, EZH2-, TNFRSF14-, CREBBP-gének szomatikus mutációi. Számottevő hasonlóság fedezhető fel az EZB DLBCL és a follikuláris limfómák molekuláris hátterében, mely alapján feltételezhető, hogy a két entitás hasonló fejlődési fázisban lévő centrum germinativum-őssejtből ered, illetve felmerül, hogy az EZB DLBCL szubtípus egy része okkult vagy korábbi manifeszt FL-ből transzformálódott DLBCL. A jövőre nézve a csoport potenciális terápiás célpontjai az EZH2, a BCL2 és a PI3K lehetnek. Az ST2 altípus kedvező prognózisú (5 éves OS: $81 \%$ ), a C4 és a TET2/SGK1, illetve a SOCS1/SGK1 szubtípusoknak felelnek meg (3. táblázat). A csoportba tartozó esetek döntő többsége a COO alapján GCB-DLBCLnek bizonyult. A csoport jellemző genetikai eltérései a TET2-, P2RY8-, SGK1-, SOCS1-, illetve egyes hisztongének mutációi. A molekuláris háttér átfedésbe hozható a noduláris limfocita predomináns Hodgkin-limfómákéval, a szöveti hisztiocita gazdag B-sejtes limfómákéval, illetve a primer mediasztinális nagy B-sejtes limfómák esetén megfigyeltekkel [26]. Az ST2 csoport lehetséges molekuláris terápiás célpontjai a PI3K és a JAK jelátviteli útvonalak. A BN2 alcsoport sejteredet szempontjából heterogén (41\% ABC-DLBCL, 40\% unclassified, 19\% GCB-DLBCL), az ötéves túlélés átlagosan $67 \%$ (3. táblázat). A csoport a $\mathrm{C} 1$ és NOTCH2 csoportokkal azonos genetikai eltérésekkel jellemezhető (mutációk a BCL6-, NOTCH2-, CD70-, BCL10-, SPEN-génekben), amelyhez hasonló molekuláris profil jellemzi a marginális zónalimfómákat is [25]. Ebben a csoportban az esetek mintegy egyötödében mutatható ki PD-L1/PD-L2-overexpreszszió (a többi DLBCL-es csoportban ez az eltérés szinte egyáltalán nem fordul elő), melyek további terápiás célpontokként szolgálhatnak a jövőben. Az A53 szubtípusba döntően az ABC-DLBCL sejteredetü esetek tartoznak, prognózisuk jellemzően kedvezőtlen (5 éves OS: 63\%) (3. táblázat). Az A53 szubtípus molekuláris jellemzőket tekintve a $\mathrm{C} 2$ csoporttal egyezik, a jövőbeni terápiában a BTK-gátló kezelés kulcsszerepet játszhat. A legrosszabb prognózisú esetek az N1 csoport tagjai (5 éves OS: 27\%), mely esetek sejteredet szempontjából ABC-DLBCL-hez sorolhatók (3. táblázat). Relatíve kisszámú eset tartozik ebbe a csoportba, csak az NCI munkacsoport különítette el ezen eseteket önálló entitásként. A jellemző genetikai eltérések a NOTCH1-, IRF2BP2-, BCOR-, IKBKB-gének, ebből adódóan rokonság feltételezhető ezen DLBCL-es és a Richter-transzformáción átesett CLL-es esetek közt. A kedvezőtlen prognózis ellenére a jövőbeni potenciális terápiás célpont lehet a $\mathrm{PD}-1$ és $\mathrm{PD}-\mathrm{L} 1 \mathrm{Az} \mathrm{MCD}$ esetek nagy része az $\mathrm{ABC}$ csoportba sorolható, mely kedvezőtlen túlélési mutatókkal rendelkezik (5 éves OS: 40\%) (3. táblázat). MYD88-, CD79B-, PIM1-, SPIB-, CDKN2A-mutációk azonosíthatók, melyek hasonlóak a primer központi idegrendszeri limfómák és egyéb extranodális limfómák molekuláris eltéréseihez. A molekuláris háttér és a génexpressziós mintázat alapján feltételezhető, hogy a DELek nagy része ebbe a csoportba tartozik. Az MCD DLBCL-es betegek személyre szabott terápiájában a jövőben szerepe lehet a BTK-, PI3K-, BCL2-, JAK- és IRF4gátlóknak.

\section{Összefoglalás}

Az utóbbi évek kutatási eredményeinek köszönhetően jelentős előrelépés történt a DLBCL klinikai gyakorlatban is alkalmazható prognosztikus és prediktív felosztásának megteremtése irányában. Új prospektív, randomizált, multicentrikus tanulmányok fogják megadni a választ arra, hogy az egyes új DLBCL alcsoportokban igazolható-e szelektíven a célzott terápiák vagy intenzívebb kemoimmunterápiás kombinációk előnye. Ezenfelül, a konvencionális kemoimmunterápiákra jól reagáló csoportoknál, a toxicitás csökkentése érdekében szóba jöhet a kemoterápia dózisának redukciója, kedvező válasz esetén a kezelés deeszkalációja.

$\mathrm{Az}$ összefoglalóban ismertetett tanulmányok kezelés előtti, diagnosztikus DLBCL-mintákat vizsgáltak, ezért felvetődik, hogy az újonnan definiált alcsoportok relabáló/refrakter DLBCL esetén mennyire reprodukálhatók. A kezelés hatására bekövetkező, később a terápiás sikertelenséget előidéző dinamikus klonális változások vizsgálatára kézenfekvő eljárás lehet a folyadékbiopszia-alapú monitorozás, melynek segítségével r/rDLBCL esetén akár minimál invazív módon vizsgálható a betegek molekuláris profilja [27]. A 2019-es Amerikai Hematológus Társaság konferenciáján a Stanford Egyetem munkacsoportja mutatta be, hogy az újonnan kialakitott DLBCL szubtípusok folyadék-biopsziás vizsgálattal is meghatározhatók, akár a diagnosztikus tumorbiopsziától függetlenül [28]. Ezen eljárás valódi klinikai hasznának validációja és bevezetése a mindennapi gyakorlatba azonban még várat magára.

Molekuláris genetikai és génexpressziós vizsgálattal az NCI munkacsoportnak a de novo DLBCL NOS esetek kétharmadát [22], a Harvard munkacsoportnak az esetek 96\%-át [23], míg a cambridge-i munkacsoportnak az esetek $70 \%$-át sikerült valamelyik genetikai alosztályba besorolni [24]. Megemlítendő, hogy a magasabb klasszi- 


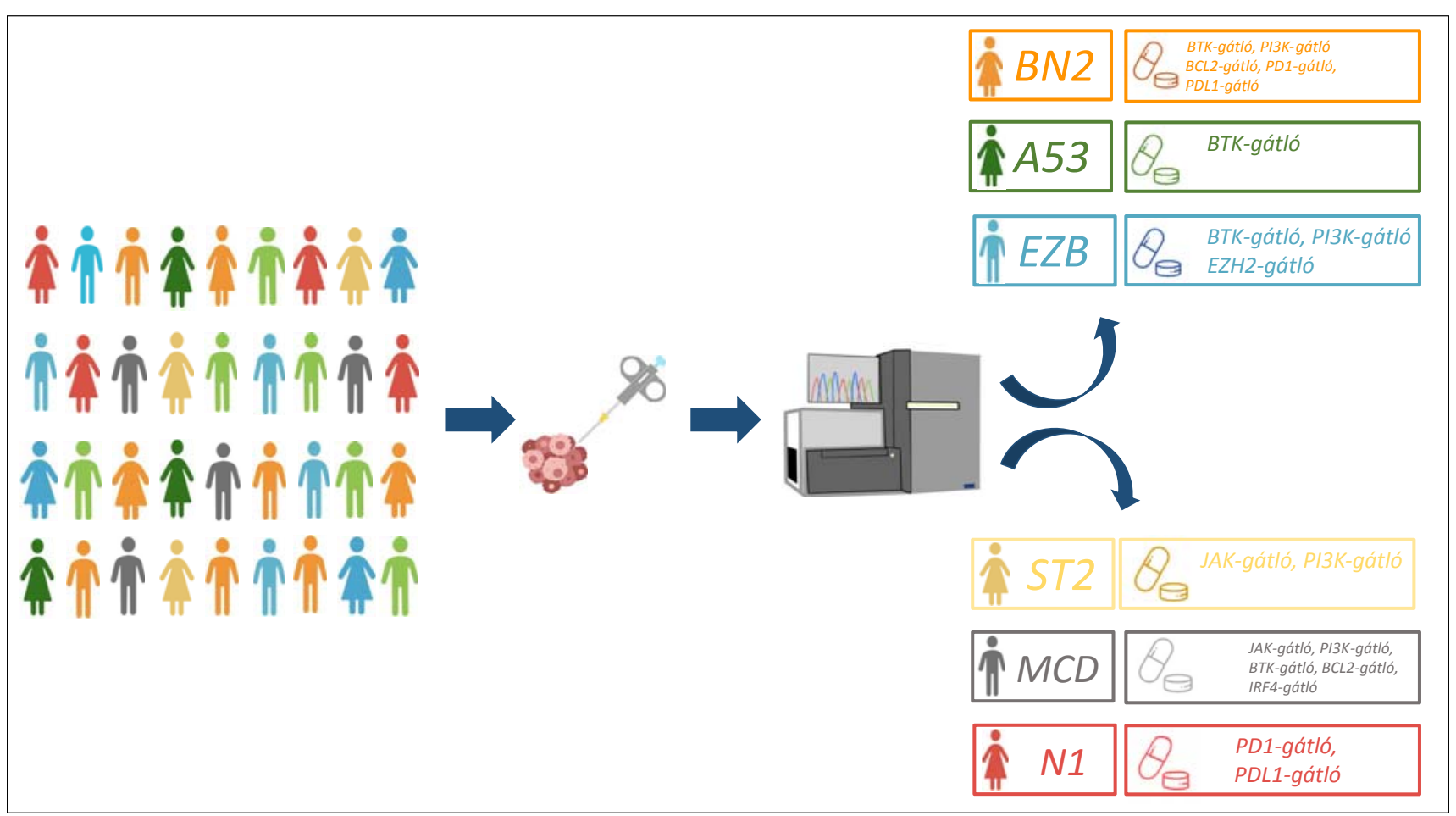

2. ábra. Az új klasszifikációs rendszerek kidolgozását elsősorban a személyre szabott daganatterápia iránti igény tette szükségessé. A folyamatábrán szemléltetjük, hogy a DLBCL betegpopuláció egy heterogén csoport, mely az egyes betegek DNS-mintáinak molekuláris biológiai analízise után pontosabb szubtípusokra osztható fel, ezáltal elképzelhető, hogy az adott csoportra jellemző molekuláris eltérések ismeretében hatékonyabb célzott terápiás ágens alkalmazható. Ezen terápiás vulnerábilitások gyakorlati tesztelése a közeljövőben várható

fikációs arány nem feltétlenül jelent sikeresebb osztályozási algoritmust, mivel például a Harvard munkacsoport magas klasszifikációs sikerét egy „megengedőbb”, kevésbé szigorú kritériumrendszer alkalmazása okozta (a Harvard munkacsoport algoritmusa is csak az esetek $70 \%$-át tudta nagy megbízhatósággal valamelyik klaszterbe [C1-C5] sorolni, az esetek további 26\%-a bizonytalan esetként lett klasszifikálva [29]). Ezek alapján kiemelendő, hogy a DLBCL NOS esetek 20-30\%-a az új molekuláris eredmények ellenére továbbra sem osztályozható. Felmerül, hogy ezen esetekben a nem kódoló genom, az epigenom, illetve a tumor-mikrokörnyezet vizsgálata segítheti a már meglévő altípusokba vagy új klaszterekbe történő besorolást [30].

DLBCL esetén a „rituximab érában” továbbra is a klinikai változókon alapuló nemzetközi prognosztikus index (IPI) bizonyult a legmegbízhatóbb prognosztikus mutatónak. Az új molekuláris eredmények fényében sem tűnik valószínűnek, hogy a klinikai jellemzők az elkövetkező években veszíteni fognak értékükből, sokkal inkább egy klinikai, morfológiai és molekuláris szempontokat is figyelembe vevő klasszifikációs és prediktív-prognosztikus rendszer megalkotása várható. Minden bizonnyal a célzott terápiák jövőbeni térhódítása mellett bizonyos indikációs megkötések is várhatók, például idős betegek esetén a célzott terápiák jellemző mellékhatás profilja limitálhatja ezen kezelések alkalmazhatóságát (például ibrutinibkezelés pitvarfibrilláló beteg esetén). Fiatal, jó prognózisú, korai stádiumú betegcsoportnál felmerül az alkalmazott, rendszeresen jól működő standard terápiás vonalak további gyógyszerekkel történő kiegészítésének szükségessége mellett az kemoimmunterápia deeszkalációja, esetleg kemoterápiamentes kombinációkra történő váltása [14].

Belátható időn belül várható, hogy a WHO is egyre nagyobb mértékben fogja beemelni az új molekuláris genetikai eredményeket a DLBCL taxonómiába, melyek remélhetőleg nemcsak a betegek alcsoportba sorolásában és a prognózis meghatározásában lesznek a kezelőorvosok segítségére, hanem a legoptimálisabb terápia megválasztásában is (2. ábra).

Nyilatkozat: A cikk nem jelent meg más folyóiratban és nem áll egyéb publikáció alatt. A levelező szerző a szerzői útmutatót elolvasta.

Érdekeltségek: A szerzőknek nincsenek érdekeltségeik. Anyagi támogatás: A közlemény az Innovációs és Technológiai Minisztérium Kooperatív Doktori Program doktori hallgatói ösztöndíj programjának Nemzeti Kutatási, Fejlesztési és Innovációs alapból finanszírozott szakmai támogatásával készült (NKFIH KDP-1022882). A közlemény elkészülését támogatta továbbá az Új Nemzeti Kiválóság Program ÚNKP-20-5-SE-22 kódszámú pályázata, a SEMMELWEIS 250+ kiválósági PhD Ösztöndíja az EFOP3.6.3-VEKOP-16-2017-00009 pályázat keretében, a Semmelweis Tudományos és Innovációs Alap STIA-KFI 
61830669322 kódszámú pályázata, az NKFIH K21-137948 pályázata, az Emberi Erőforrások Minisztériumának Felsőoktatási Intézményi Kiválósági Programja, a Semmelweis Egyetem Molekuláris Biológia tématerületi programja keretében, valamint az Európai Unió H2020 (SGA No. 739593) programja.

Szerzői munkamegosztás: K.L., N.Á.: a kézirat írása, ábrakészítés. B.B., B.Cs.: a kézirat javítása és véleményezése. A kéziratot valamennyi szerző elolvasta és jóváhagyta.

\section{Irodalom}

[1] Morton LM, Wang SS, Devesa SS, et al. Lymphoma incidence patterns by WHO subtype in the United States, 1992-2001. Blood 2006; 107: 265-276.

[2] Crump M, Neelapu SS, Farooq U, et al. Outcomes in refractory diffuse large B-cell lymphoma: results from the international SCHOLAR-1 study. Blood 2017; 130(16): 1800-1808. Blood 2018; 131: 587-588.

[3] Swerdlow SH, Campo E, Pileri SA, et al. The 2016 revision of the World Health Organization classification of lymphoid neoplasms. Blood 2016; 127: 2375-2390.

[4] Alizadeh AA, Eisen MB, Davis RE, et al. Distinct types of diffuse large B-cell lymphoma identified by gene expression profiling. Nature 2000; 403: 503-511.

[5] Dunleavy K, Fanale MA, Abramson JS, et al. Dose-adjusted EPOCH-R (etoposide, prednisone, vincristine, cyclophosphamide, doxorubicin, and rituximab) in untreated aggressive diffuse large B-cell lymphoma with MYC rearrangement: a prospective, multicentre, single-arm phase 2 study. Lancet Haematol. 2018; 5: e609-e617.

[6] Oki Y, Noorani M, Lin P, et al. Double hit lymphoma: the MD Anderson Cancer Center clinical experience. Br J Haematol. 2014; 166: 891-901.

[7] Petrich AM, Gandhi M, Jovanovic B, et al. Impact of induction regimen and stem cell transplantation on outcomes in double-hit lymphoma: a multicenter retrospective analysis. Blood 2014; 124 2354-2361.

[8] Bartlett NL, Wilson WH, Jung SH, et al. Dose-Adjusted EPOCH-R compared with R-CHOP as frontline therapy for diffuse large B-cell lymphoma: Clinical outcomes of the Phase III Intergroup Trial Alliance/CALGB 50303. J Clin Oncol. 2019; 37: 1790-1799.

[9] Davies A, Cummin TE, Barrans S, et al. Gene-expression profiling of bortezomib added to standard chemoimmunotherapy for diffuse large B-cell lymphoma (REMoDL-B): an open-label, randomised, phase 3 trial. Lancet Oncol. 2019; 20: 649-662.

[10] Younes A, Sehn LH, Johnson P, et al. Randomized Phase III Tria of ibrutinib and rituximab plus cyclophosphamide, doxorubicin, vincristine, and prednisone in non-germinal center B-cell diffuse large B-cell lymphoma. J Clin Oncol. 2019; 37: 1285-1295.

[11] Nowakowski GS, Chiappella A, Witzig TE, et al. ROBUST: Lenalidomide-R-CHOP versus placebo-R-CHOP in previously untreated ABC-type diffuse large B-cell lymphoma. Future Oncol. 2016; 12: 1553-1563.

[12] Zelenetz AD, Salles G, Mason KD, et al. Venetoclax plus R- or G-CHOP in non-Hodgkin lymphoma: results from the CAVALLI phase 1b trial. Blood 2019; 133: 1964-1976.
[13] Morschhauser F, Feugier P, Flinn IW, et al. Venetoclax plus rituximab, cyclophosphamide, doxorubicin, vincristine and prednisolone (R-CHOP) improves outcomes in BCL2-positive first-line diffuse large B-cell lymphoma (DLBCL): First safety, efficacy and biomarker analyses from the Phase II CAVALLI Study. Blood 2018; 132: 782-782.

[14] Crombie JL, Armand P. Diffuse large B-cell lymphoma's new genomics: The bridge and the chasm. J Clin Oncol. 2020; 38: 3565-3574.

[15] Frosch ZAK, Landsburg DJ. Molecular risk stratification in aggressive B-cell lymphomas. J Clin Oncol. 2020; 38: 2014-2017.

[16] Ennishi D, Jiang A, Boyle M, et al. Double-hit gene expression signature defines a distinct subgroup of germinal center B-celllike diffuse large B-cell lymphoma. J Clin Oncol. 2019; 37: 190201.

[17] Hilton LK, Tang J, Ben-Neriah S, et al. The double-hit signature identifies double-hit diffuse large B-cell lymphoma with genetic events cryptic to FISH. Blood 2019; 134: 1528-1532.

[18] Sha C, Barrans S, Cucco F, et al. Molecular high-grade B-Cell lymphoma: Defining a poor-risk group that requires different approaches to therapy. J Clin Oncol. 2019; 37: 202-212.

[19] Cucco F, Barrans S, Sha C, et al. Distinct genetic changes reveal evolutionary history and heterogeneous molecular grade of DLBCL with MYC/BCL2 double-hit. Leukemia 2020; 34: 1329-1341.

[20] Lenz G, Wright G, Dave SS, et al. Stromal gene signatures in large-B-cell lymphomas. N Engl J Med. 2008; 359: 2313-2323.

[21] Staiger AM, Altenbuchinger M, Ziepert M, et al. A novel lymphoma-associated macrophage interaction signature (LAMIS) provides robust risk prognostication in diffuse large B-cell lymphoma clinical trial cohorts of the DSHNHL. Leukemia 2020; 34: 543-552.

[22] Schmitz R, Wright GW, Huang DW, et al. Genetics and pathogenesis of diffuse large B-cell lymphoma. N Engl J Med. 2018; 378: 1396-1407.

[23] Chapuy B, Stewart C, Dunford AJ, et al. Molecular subtypes of diffuse large B cell lymphoma are associated with distinct pathogenic mechanisms and outcomes. Nat Med. 2018; 24: 679-690.

[24] Lacy SE, Barrans SL, Beer PA, et al. Targeted sequencing in DLBCL, molecular subtypes, and outcomes: a Haematological Malignancy Research Network report. Blood 2020; 135: 1759-1771.

[25] Wright GW, Huang DW, Phelan JD, et al. A probabilistic classification tool for genetic subtypes of diffuse large B cell lymphoma with therapeutic implications. Cancer Cell 2020; 37: 551-568 e14.

[26] Morin RD, Scott DW. DLBCL subclassification: divide and conquer? Blood 2020; 135: 1722-1724.

[27] Nagy Á, Bátai B, Kiss L, et al. Folyadékbiopszia-vizsgálatok alkalmazási lehetőségei az onkohematológiában. HematológiaTranszfuziológia 2020; 53: 144

[28] Esfahani MS, Alig S, Kurtz DM, et al. Towards non-invasive classification of DLBCL genetic subtypes by Ctdna profiling. Blood 2019; 134: 551-551.

[29] Chapuy B, Stewart C, Wood T, et al. Validation of the genetically-defined DLBCL subtypes and generation of a parsimonious probabilistic classifier. Blood 2019; 134: 920.

[30] Ennishi D, Hsi ED, Steidl C, et al. Toward a new molecular taxonomy of diffuse large B-cell lymphoma. Cancer Discov. 2020; 10: 1267-1281.

A cikk a Creative Commons Attribution 4.0 International License (https://creativecommons.org/licenses/by/4.0/) feltételei szerint publikált Open Access közlemény, melynek szellemében a cikk bármilyen médiumban szabadon felhasználható, megosztható és újraközölhető, feltéve, hogy az eredeti szerző és a közlés helye, illetve a CC License linkje és az esetlegesen végrehajtott módosítások feltüntetésre kerülnek. (SID_1) 